\title{
SISTEM INFORMASI PROSES AKUNTASI MENGGUNAKAN SAK-ETAP BERBASIS WEB PADA PELAKU USAHA
}

\author{
${ }^{1)}$ Puspita Rama Nopiana, ${ }^{2}$ Evan Rosiska \\ 1) Akuntansi, ${ }^{2)}$ Sistem Informasi, Universitas Putera Batam \\ J1. Letjen R Soeprapto, Batam 29433 \\ E-Mail:ramanopiana@gmail.com,evan.rosiska@yahoo.com
}

\begin{abstract}
ABSTRAK
Banyaknya pelaku usaha yang dimaksud adalah UKM (Usaha Kecil dan Menenggah), dimana kegiatannya hanya fokus pada operasional usaha saja tampa memperhatikan kinerja keuangan untuk jangka panjang. Hal ini menyebabkan masalah sulitnya UKM untuk bertahan lama dalam membangun usahanya, ditambah lagi kurangnya pengetahuan dibidang akuntansi terutama UKM di Kota Batam. Tujuan penelitian yaitu merancang sistem informasi proses akuntansi sesuai Standar Akuntansi Keuangan Entitas Tanpa Akuntabilitas Publik (SAK-ETAP) berbasis Web pada pelaku usaha kecil. Metode penelitian yang digunakan adalah eksperimen untuk merancang proses sistem informasi proses akuntansi perusahaan yang bergerak dibidang jasa, dagang dan manufaktur. Hasil penelitian menjelaskan bahwa sistem informasi proses akuntansi dalam pembuatan laporan keuangan sangat dibutuhkan UKM, dimana saat ini penyajian laporan keungan masih disajikan secara manual. Sistem informasi yang dirancang berbentuk software akuntansi diberi nama Sistem Informasi Laporan Keuangan Berstandar Entitas Tanpa Akuntabilitas Publik yang disingkat dengan "SIKBAP Accounting". Software yang disajikan ini mampu membatu pelaku usaha dalam menyajikan kinerja keuangan menyusun laporan keuangan terdiri dari neraca awal, jurnal umum, buku besar, neraca saldo, jurnal penyesuaian yang diproses secara komputerisasi sehingga memberikan output berupa laporan keuangan yaitu laporan laba/rugi, laporan perubahan ekuitas, dan laporan neraca.
\end{abstract}

Kata Kunci: Information System, Accounting Process, SAK-ETAP, Web, Businessmen

\section{ABSTRACT}

The number of entrepreneurs in question is SMEs (Small and Holding Enterprises), where its activities only focus on business operations alone tampa pay attention to financial performance for the long term. This causes the difficulty of SMEs to last long in building their business, plus the lack of knowledge in the field of accounting, especially SMEs in the city of Batam. The purpose of the research is to design an accounting process information system in accordance Financial Accounting Standards Entity Without Public Accountability (SAK-ETAP) on the small business actors. The research method used is the experiment to design the process of information system of accounting process of companies engaged in services, trade and manufacturing. The results explain that the accounting process information system in the preparation of financial statements are needed SMEs, which currently presenting financial statements are still presented manually. The information system designed in the form of accounting software is named Financial Statement Information System Standardized Entity Without Public Accountability abbreviated with "SIKBAP Accounting". The software presented is able to petrify business actors in presenting the financial performance of preparing financial statements consisting of the initial balance sheet, general journal, ledger, trial balance, adjustment journal processed computerized so as to provide output in the form of income statement, statement of owner equity, balance sheet.

Keywords: Information System, Accounting Process, SAK-ETAP, Web, Businessmen

PENDAHULUAN

Menyongsong Masyarakat Ekonomi ASEAN (MEA) pada tahun 2016 yang merupakan bentuk integrasi ekonomi ASEAN dalam sistem perdagangan bebas antara negara-negara ASEAN. Artikel (Rofiq, 2016) menjelaskan bahwa UKM menjadi bagian yang penting bagi roda perekonomian tanah air, dan juga memegang peranan penting bagi 
perekonomian ASEAN hingga saat ini 96\% dari perusahaan ASEAN merupakan UKM, dimana $50 \%$ memberikan kontribusi 30\% sampai 53\% dari produk domestik bruto (PDB), dan berkontribusi 19\% sampai 31\% dari ekspor. Pemerintah Indonesia membina UKM melalui Dinas Koperasi dan UKM di masing-masing Provinsi atau Kabupaten/Kota. Indonesia merupakan negara yang memiliki UKM/UMKM terbesar sejak tahun 2014. Berdasarkan Data Kementerian Koperasi dan UKM, jumlah wirausahawan di Indonesia pun melonjak tajam dari 0,24\% menjadi $1,56 \%$ dari jumlah penduduk Indonesia.

Pentingnya UKM, maka Pemerintah Indonesia sudah mengatur secara khusus kewajiban tentang UKM untuk menyusun laporan keuangan. Peraturan tersebut dituangkan dalam Standar Akuntansi Keuangan (SAK-ETAP) yang sudah diterbitkan oleh Ikatan Akuntan Indonesia pada 19 Mei 2009. Tuntutan terhadap penyajian laporan keuangan merupakan komponen yang harus dipenuhi sebagai informasi keuangan terutama dalam memperluas usaha dan jika pengusahan ingin mengembangkan usaha dengan mengajukan modal kepada para kreditur yang dalam hal ini adalah pihak perbankan (Setyawan, 2017). Kendala yang dihadapi UKM berdasarkan wawancara dengan perwakilan UKM terutama di Kota Batam antara lain disebabkan: (1) rendahnya pendidikan dan pengetahuan pelaku usaha dibidang akuntansi, sehingga penyusunan laporan keuangan belum sesuai dengan standar yang berlaku secara umum (2) kurangnya pemahaman teknologi informasi, padahal pelaku usaha kecil dan menengah dituntut memahami teknologi informasi agar rencana yang diprogramkan dapat dijalankan dengan baik, (3) kurangnya keandalan karakteristik laporan keuangan, karena menyusun laporan keuangan masih bersifat manual, sehingga pemenuhan karakteristik kualitatif laporan keuangan jauh dari harapan khususnya memberikan informasi keuangan yang handal. Permasalahan ini didukung oleh penelitian terdahulu yang menjelaskan bahwa rata-rata $40 \%$ penerapan akuntansi bagi UMKM Kecamatan Sukajadi Binaan Dinas Koperasi dan UMKM Kota Pekanbaru secara lengkap atau sesuai tahapan-tahapan dalam siklus akuntansi serta sesuai dengan SAK ETAP. Selanjutnya $60 \%$ penerapan akuntansi masih dalam bentuk sangat sederhana dan belum sesuai dengan SAK ETAP (Salmiah, Neneng, 2015).

Permasalahan di atas dipertegas dalam artikel (Suhairi, 2006) yang menyebutkan bahwa Standar Akuntansi Keuangan (SAK) dirasakan sangat memberatkan bagi Usaha Kecil dan Menengah dibandingkan dengan usaha besar. Salah satu faktor sebagai penyebab terjadiya overload adalah rendahnya tingkat penyusunan laporan keuangan pada UKM, dan adanya kewajiban UKM yang sama dengan usaha besar. Dengan kata lain, UKM diwajibkan membuat laporan keuangan sesuai dengan standar akuntansi keuangan internasional. Mengatasi masalah tersebut maka, diperlukan adanya standar dalam penyusunannya, dengan tujuan untuk memudahkan dalam memahami laporan keuangan (laporan keuangan). Kehadiran 
SAK-ETAP diharapkan dapat memberikan kemudahan untuk UKM dalam menyajikan laporan keuangan.

Penelitian ini bermaksud untuk merancang aplikasi pembuatan software laporan keuangan. Hasil berdasarkan SAK-ETAP yang diberi nama "SIKBAP Accounting" (Sistem Informasi Keuangan Berbasis ETAP-Akuntansi) dengan bahasa pemograman PHP berbasis web. Tujuan penelitian yaitu merancang sistem informasi proses akuntansi sesuai Standar Akuntansi Keuangan Entitas Tanpa Akuntabilitas Publik (SAK-ETAP) berbasis Web pada pelaku usaha kecil. Metode penelitian eksperimen dalam merancang sistem informasi proses akuntansi perusahaan yang bergerak dibidang jasa, dagang dan manufaktur. Metode penelitian eksperimen, dengan sasaran merancang software laporan keuangan perusahaan yang bergerak dibidang jasa, dagang dan manufaktur (CV, Fa, PO, PT belum go publik).

Analisis kebutuhan dari survei yang dilakukan pada objek perwakilan UKM yaitu CV Khazanah Century Auto mewakili rancangan perusahaan jasa dan PT Hijrah Prima Utama untuk perusahaan dagang dan industri menjelaskan bahwa perusahaan menyusun laporan keuangan sudah menggunakan komputerisasi dengan program Ms. Excel. Tentunya hal ini masih dianggap besifat manual karena belum efektif dan efesien, sehingga diperlukan rancangan aplikasi proses akuntansi menggunakan SAK-ETAP. Hasil penelitian ini memiliki kontribusi kepada UKM dalam mempermudah menyajikan proses akuntansi sampai menyusun laporan keuangan perusahaan berdasarkan standar yang telah ditetapkan sesuai dengan peraturan yang berlaku.

\section{Pelaku Usaha Kecil}

Pelaku usaha kecil atau biasa yang disebut dengan Usaha Kecil Menengah (UKM). Menurut Kementrian Keuangan Berdasarkan Keputusan Menteri Keuangan Nomor 316/KMK 016/1994 tanggal 27 Juni 1994 bahwa Usaha Kecil sebagai perorangan/badan usaha yang telah melakukan kegiatan/usaha yang mempunyai penjualan/omset pertahun setinggi-tingginya $\mathrm{Rp} \quad 600.000 .000$ atau asset (aktiva) setinggi-tingginya $\mathrm{Rp}$ 600.000.000 (diluar tanah dan bangunan yang ditempati). Usaha Kecil dan Menengah (UKM) dengan kadar pemahaman teknologi yang tinggi mempunyai kemungkinan mengadopsi dan memanfaatkan teknologi informasi secara intensif. Menurut (Thee, Kian W, 1991) dikutip oleh (Rifqi, 2009) pada umumnya UKM di negara sedang berkembang menghadapi masalah serius dalam pengembangan usahanya karena terbatasnya kemampuan teknologi.

UKM dituntut untuk memahami teknologi informasi hanya untuk sebagai user atau pengguna, bukan berarti merancang sendiri. UKM dapat menggunakan rancangan aplikasi yang akan dilakukan oleh penelitian ini akan membantu UKM untuk bisa mengunakan teknologi dalam menyusun laporan keuangannya baik perusahaan bergerak dibidang jasa, dagang dan manufaktur (industri) pada CV, Fa, PO, PT non Tbk. di Kota Batam. 
Implementasi Sistem Informasi Akuntansi

Sistem (system) adalah kumpulan subsub sistem, elemen-elemen, prosedurprosedur, yang saling berintegrasi untuk mencapai tujuan tertentu, seperti informasi, target atau goal. Karakter suatu sistem terdiri dari: komponen (component), batas sistem (boundary), lingkungan luar sistem (environments), Penghubung (interface), input process dan output, Sasaran (objectives) dan tujuan (goal) (Sutabri, 2012).

Informasi adalah sekumpulan fakta (data) yang diorganisasikan dengan cara tertentu, sehingga mereka mempunyai arti bagi penerima (Sutarman, 2012) Sedangkan Menurut Gordon B. Davis yang diterjemahkan (Mardi, 2014) menyatakan Informasi adalah data yang telah diolah ke dalam suatu bentuk yang berguna bagi penerimanya dan nyata atau berupa nilai yang dapat dipahami di dalam keputusan sekarang maupun masa depan.

Akuntansi adalah proses mengidentifikasikan, mengukur, dan menyampaikan informasi ekonomi sebagai bahan informasi dalam hal mempertimbangkan berbagai alternatif dalam mengambil kesimpulan oleh para pemakainya. Akuntansi adalah bahasa atau alat komunikasi bisnis yang dapat memberikan infromasi tentang kondisi keuangan (ekonomi) berupa posisi keuangan terutama dalam jumlah kekayaan, utang dan modal dari suatu bisnis (Syafri, 2008).

Berdasarkan penjelasan di atas, maka sistem informasi akuntansi merupakan proses transaksi keuangan dan transaksi non keuangan yang mempengaruhi pemrosesan transaksi keuangan dan terdapat pemrosesan data didalamnya. Pemahaman pengelola UKM terhadap pentingnya informasi akuntansi berbasis teknologi, hal ini disebabkan informasi akuntansi digunakan sebagai pedoman dalam pengambilan keputusan dan mencapai efisiensi dan efektifitas.

\section{Laporan keuangan}

Laporan keuangan adalah hasil proses akuntansi yang dapat digunakan sebagai alat untuk berkomunikasi antara data keuangan atau aktivitas suatu perusahaan dengan pihak-pihak yang berkepentingan dengan data atau aktivitas tersebut (Irham, 2012). Lebih lanjut (Syafri, 2008) berpendapat bahwa, laporan keuangan adalah output dan hasil akhir dari proses akuntansi. Laporan keuangan inilah yang menjadi bahan informasi bagi para pemakainya sabagai salah satu bahan dalam proses pengambilan keputusan. Disamping sebagai informasi, laporan keuangan juga sebagai pertanggung jawaban atau accountability yang digunakan sekaligus gambaran indikator kesuksesan suatu perusahaan dalam mencapai tujuannya.

Informasi keuangan ini dapat bermanfaat oleh pemakainya sebagai salah satu bahan dalam pengambilan keputusan. Laporan keuangan yang lengkap terdiri dari komponen-komponen yaitu neraca (balance sheet), laporan laba/rugi (income statement), laporan perubahan ekuitas, arus kas (cash flow statement) dan catatan atas laporan keuangan. Komponen-komponen laporan keuangan disajikan dalam penelitian ini sesuai standar akuntansi keuangan (SAK-ETAP). 
Standar laporan keuangan (Laporan Keuangan)

Standar Akuntansi Keuangan adalah pernyataan dan interpretasi yang disusun oleh Dewan Standar Akuntansi Keuangan Ikatan Akuntansi Indonesia. Ikatan Akuntan Indonesia menyatakan Standar akuntansi tersebut berguna sebagai pedoman atau acuan dalam penyusunan laporan keuangan sehingga laporan keuangan entitas menjadi lebih seragam dengan standar akuntansi yang berlaku.

Standar laporan keuangan yang berlaku di Indonesia terdiri dari 4 (empat) standar yaitu: (1) Standar Akuntansi Keuangan (SAK Umum) yang dikonvergensi ke IFRS, (2) Standar Akuntansi Keuangan ETAP (SAK-ETAP), (3) Standar Akuntansi Syariah, (4) Standar Akuntansi Pemerintah (SAP). Penelitian ini membahas tentang Standar Akuntansi Keuangan ETAP (SAK ETAP), dimana SAK-ETAP digunakan oleh perusahaan yang tidak memiliki akuntabilitas publik.

\section{Aplikasi Berbasis Web}

Web merupakan suatu aplikasi perangkat lunak komputer yang dikodekan dalam bahasa yang didukung penjelajah web (seperti HTML, Javascript, AJAX, ava, dll ) dan bergantung pada penjelajah tersebut untuk menampilkan aplikasi Aplikasi adalah suatu subkelas perangkat lunak komputer yang memanfaatkan kemampuan komputer langsung untuk melakukan suatu tugas yang diinginkan pengguna.

Perancangan merupakan gambaran, perencanaan, dan pembuatan sketsa atau pengaturan dari beberapa elemen yang terpisah ke dalam satu kesatuan yang utuh dan berfungsi (Rosa \& Salahuddin, 2011). Perancangan sistem informasi laporan keuangan SAK-ETAP membutuhkan software penyimpanan data, adapun nama lain dari software penyimpanan data adalah database.

Javascript menurut (Sunyoto, 2007) adalah bahasa scripting yang popular di internet dan dapat bekerja di sebagian besar browser popoler seperti Internet Explorer (IE), Mozilla Firefox, Netscape dan Opera. Javascript memiliki fitur: high-level programming language, client-side, loosely tiped, dan berorientasi objek. Javascript pada awal perkembangannya berfungsi untuk membuat interaksi antara user dengan situs web menjadi lebih cepat tanpa harus menunggu pemrosesan di web server. Sebelum javascript, setiap interaksi dari user harus diproses oleh web server.

HTML merupakan singkatan dari Hyper Text Markup Language. HTML biasa disebut paling dasar dan penting yang digunakan untuk menampilkan dan mengelola tampilan pada halaman web. PHP adalah Bahasa server-side-scripting yang menyatu dengan HTML untuk membuat halaman web yang dinamis. Bahkan Framework dan CMS (Content Management System) juga menggunakan PHP dalam pembuatannya.

XAMPP merupakan software instalasi webserver yang disediakan secara gratis (Madcoms, 2010) yang dapat dijadikan instalasi software pendukung web server, yaitu Apache, PHP, php MyAdmin, dan database MySQL. XAMPP merupakan software yang mudah digunakan, gratis dan mendukung instalasi di Linux dan 
Windows. Keuntungan lainnya adalah cuma menginstal satu kali sudah tersedia Apache Web server, MySQL Database Server, PHP Support (PHP 4dan PHP 5) dan beberapa module lainnya. Adapun kerangka konseptual penelitian ini dapat digambarkan sebagai berikut:

\section{METODE}

Penelitian yang akan dilakukan merupakan penelitian studi kasus pada UKM di Kota Batam. Adapun salah satu objek perwakilan dalam membangun rancangan dan mengidentifikasi masalah dari penelitian ini mengambil sampel objek pada CV Khazanah Century Auto mewakili rancangan perusahaan jasa dan PT Hijrah Prima Utama untuk perusahaan dagang dan industri. Penelitian ini membuat rancangan sistem informasi laporan keuangan berstandar Entitas Tanpa Akuntabilitas Publik (ETAP) yang diberi nama "SIKBAP Accounting” (Sistem Informasi Keuangan Berstandar ETAP) Akuntansi.

Penyusunan laporan keuangan penelitian ini menggunakan metode penelitian eksperimen. Menurut (Roestiyah, 2012) penggunaan metode eksperimen ini mempunyai tujuan menemukan sendiri berbagi jawaban atas persoalan-persoalan yang dihadapinya dengan mengadakan percobaan sendiri. Pengamatan dalam memahami dan menganalisis laporan keuangan pada UKM dengan membuat sistem informasi laporan keuangan berstandar Entitas Tanpa Akuntabilitas Publik (ETAP). Perancangan atau pengembangan sistem yang digunakan adalah waterfall, dengan bentuk pemodelan yang digunakan sebagai berikut:

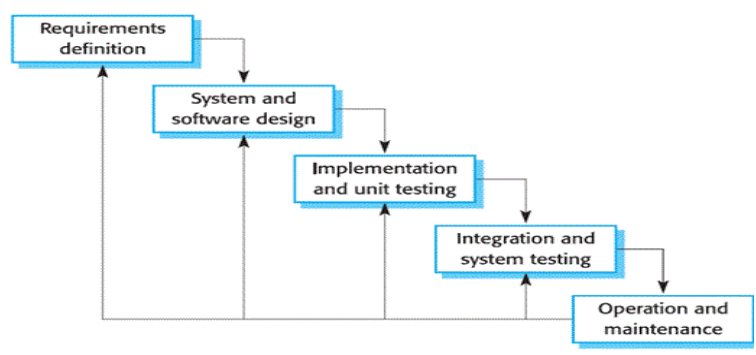

Gambar 2. Desain pembangunan perangkat lunak

\section{HASIL}

\section{Perancangan Sistem Informasi}

Tahapan perancangan sistem, dimulai dengan menganalisis kebutuhan, Design system, Implemention dan satuan pengujian, Integritas dan pengujian program, operasi dan pemeliharaan dengan penjelasan terdiri dari:

1. Analisis Kebutuhan. Tahap analisis kebutuhan sistem dimulai dengan mengidentifikasi masalah. Permasalahan ini dilakukan dengan mengumpulkan teknik pengumpulan data melalui wawancara pada UKM yang menjadi pewakilan yaitu CV. Khazanah Century Auto untuk perusahaan jasa dan PT Hijrah Prima Utama untuk perusahaan dagang dan manufaktur. Permasalahan yang didapatkan pada umumnya adalah pengolahan laporan keuangan masih bersifat manual, meskipun sudah mengunakan komputer tetapi proses dan penyimpanan masih mengunakan Ms. Excel.

2. Perancangan Sistem (Desain System). Perancangan sistem dilakukan dengan dapat dilakukan dengan beberapa tahapan yaitu: a) rancangan diagram 
entitas (Diagram E- R), b) Tahapan membuat diagram konteks untuk memberikan pandangan/gambaran umum sistem sebagai suatu proses. Diagram kontek merupakan diagram DAD level 0 yang memperlihatkan sistem sebagai satu proses, c) Tahapan membuat rancangan diagram alir data (DFD). Dalam perancangan DFD, sistem akan menurunkan DFD ke beberapa level yang lebih kecil diantaranya DFD level 1 dan level 2. DFD sendiri dibagi menjadi beberapa level, yang tiap-tiap level akan menggambarkan aliran kerja sistem informasi laporan keuangan menjadi lebih detail dan terperinci.

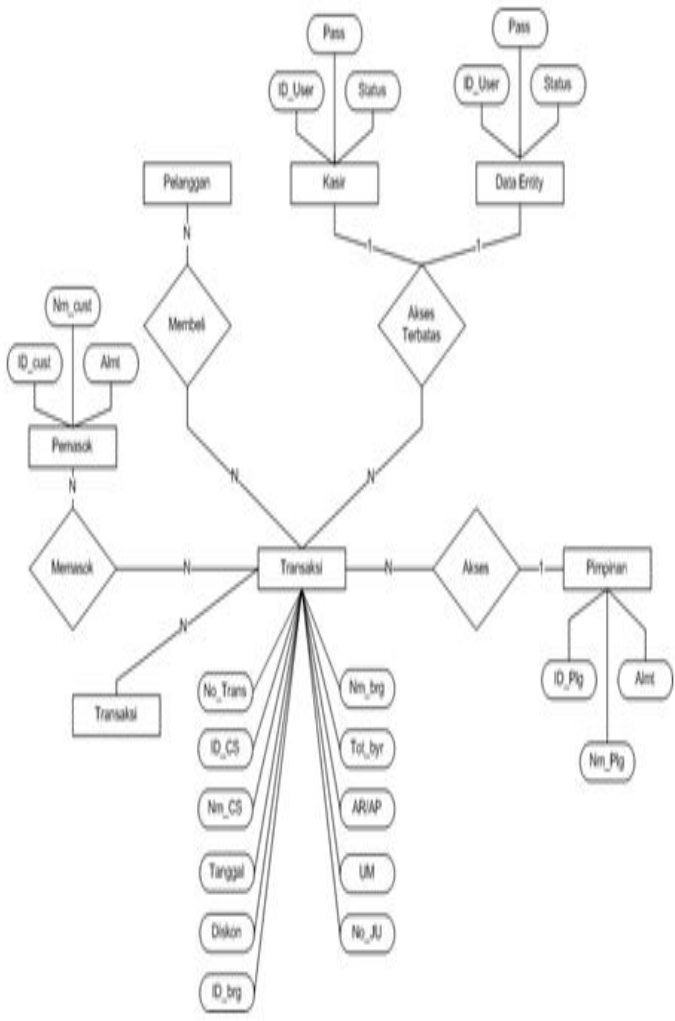

Gambar 3. Diagram E- R (Entity

Relationship)

SIKBAP Accounting

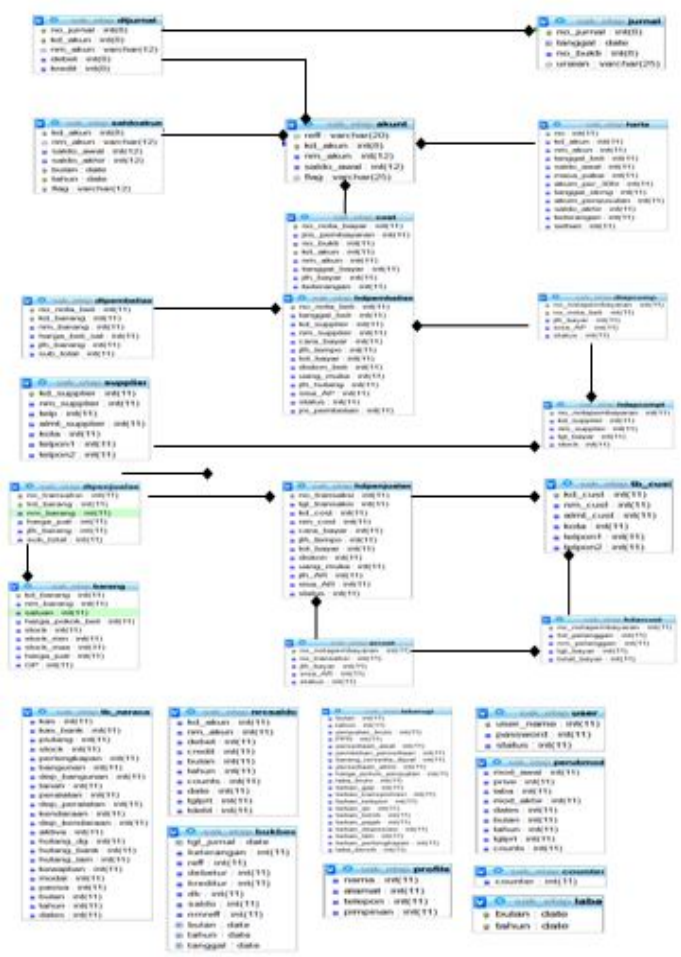

Gambar 4. Diagram Relasi Database SIKBAP Accounting

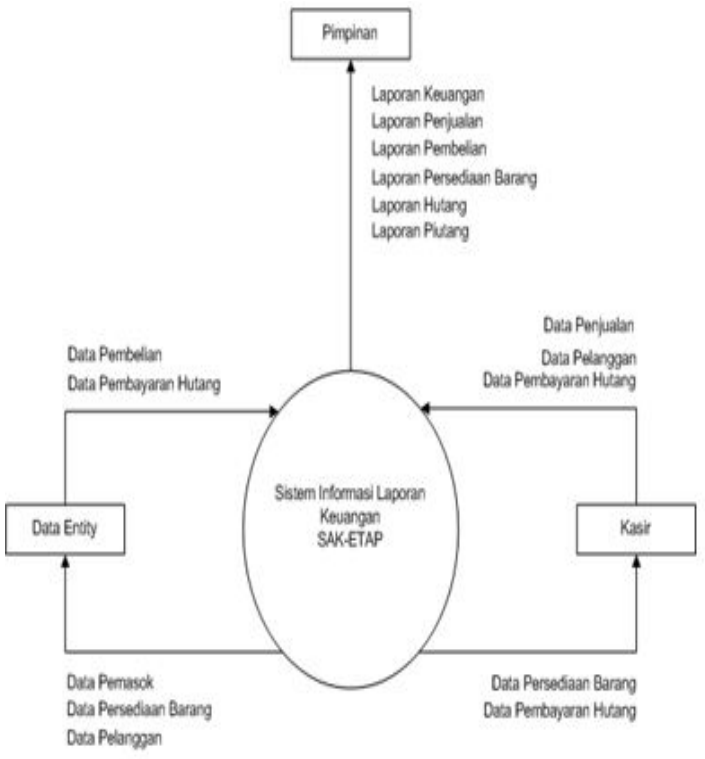

Gambar 5. Diagram Konteks SIKBAP Accounting 


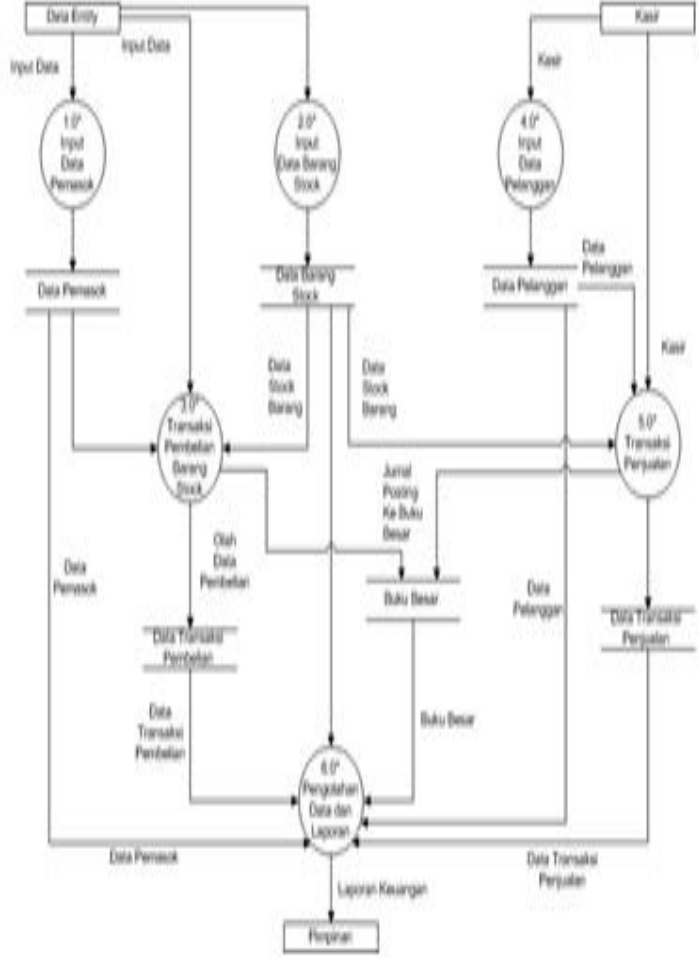

Gambar 6. DFD Level 1 Gambar

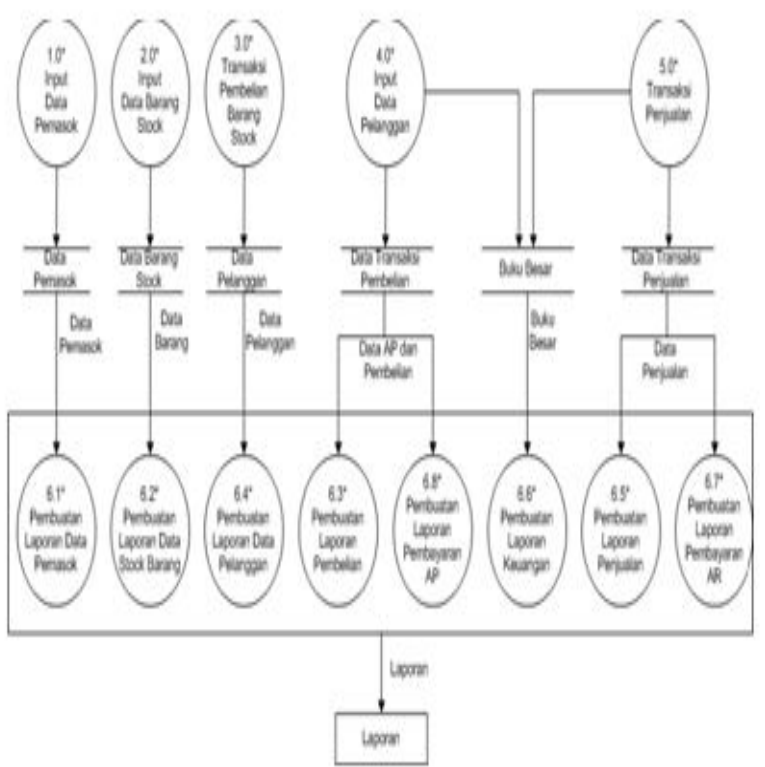

Gambar 7. Level 2 Proses Pembelian SIKBAP Accounting

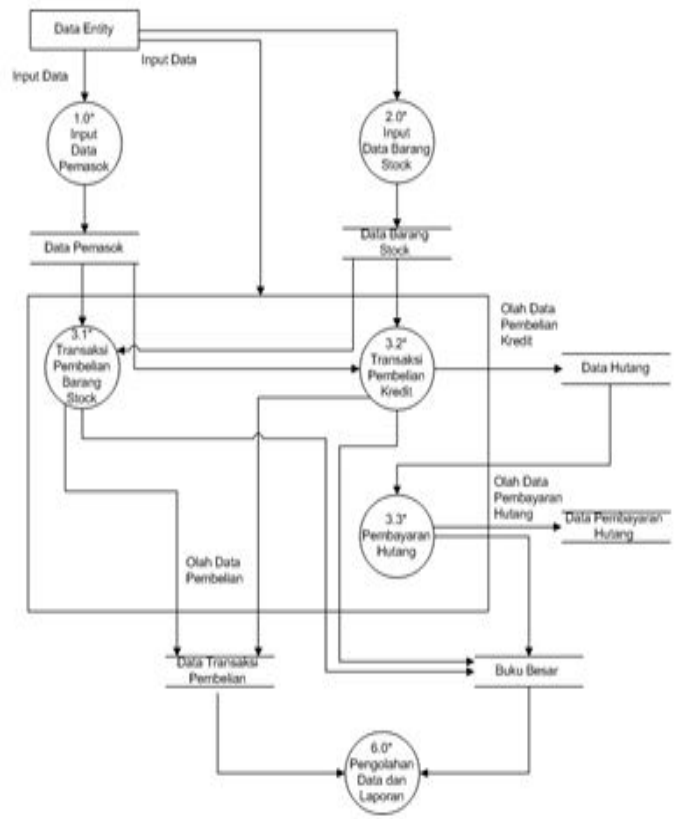

Gambar 8. Level 2 Penjualan SIKBAP Accounting

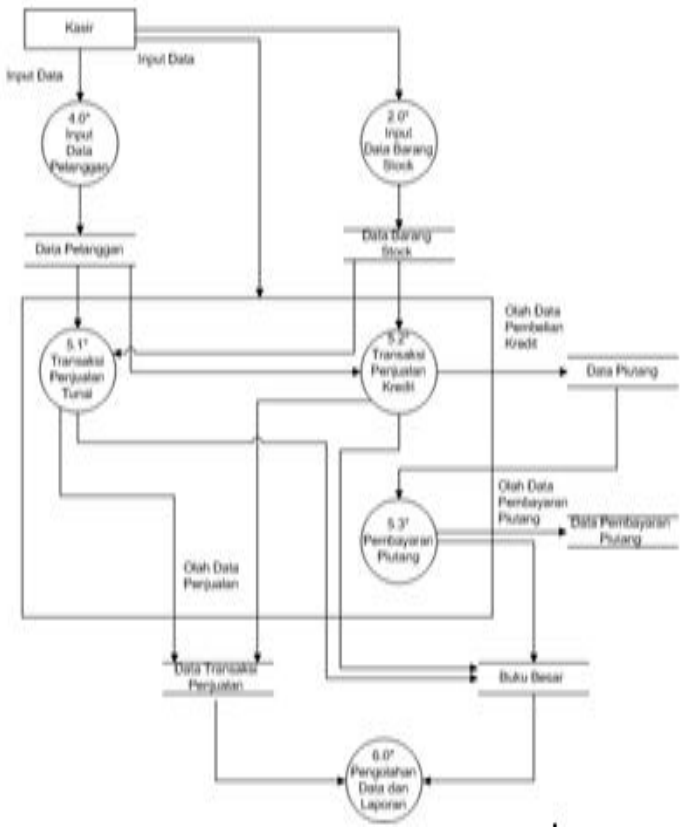

Gambar 9. Pembuatan Laporan SIKBAP Accounting

3. Implemention dan Satuan Pengujian. Tahap implementasi merupakan tahap 
penerapan sistem supaya dapat dioperasikan. Pada tahap ini dijelaskan mengenai, implementasi perangkat lunak, implementasi perangkat keras, implementasi basis data, implementasi instalasi program, penggunaan program dan implementasi antar muka. Implementasi Antar Muka. Interface yang akan ditampilkan kepada user yaitu login, sign-up, form sebuah aplikasi sistem informasi laporan keuangan berdasarkan SAK-ETAP. Pada interface login hanya ada beberapa objek sebagai berikut

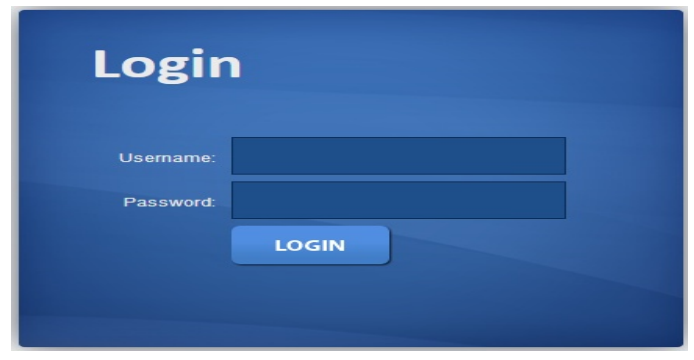

Gambar 10. Interface login SIKBAP Accounting

4. Integritas dan Pengujian Program. Integritas dan pengujian progrma tentang implementasi aplikasi SIKBAP Accounting untuk UKM di Kota Batam dengan menggunakan metode black box. Pengujian black box adalah pengujian aspek fundamental sistem tanpa memperhatikan struktur logika internal perangkat lunak. Metode ini digunakan untuk mengetahui apakah perangkat lunak ini berfungsi dengan benar. Hasil pengujian yang dirancang adalah proses login, pengujian form penjualan, pengujian form buku besar, pengujian form nerca saldo, pengujian form laporan laba/rugi, pengujian from perubahan modal, pengujian form neraca.

5. Operasi dan Pemeliharaan. Tahapan ini bisa dikatakan final dalam pembuatan sebuah software atau sistem aplikasi SIKBAP Accounting untuk UKM di Kota Batam, dimana setelah melakukan analisis, desain dan pengkodean maka sistem yang sudah jadi akan digunakan oleh user. Kemudian software yang telah dijalankan dan dibuat harus dilakukan pemeliharaan secara berkala. Kelebihan dari sistem ini adalah selain karena pengaplikasian menggunakan sistem sangat mudah, makasistem juga dapat dirasakan ketika semua kebutuhan sistem digunakan secara utuh, eksplisit, dan benar dalam menyajikan laporan keuangan.

\section{Rancangan Laporan keuangan}

Rancangan Laporan keuangan mengikuti suatu proses akuntansi yang dimulai dari dokumen transaksi dan dicatat ke jurnal, buku besar, neraca awal atau saldo, jurnal penyesuaian, kertas kerja dan laporan keuangan (laporan laba/rugi, laporan perubahan ekuitas, laporan neraca). Penyajian akun bersifat standar dan user dapat menambah akun yang tidak digunakan. Adapun rancangan akun yang disajikan didalam SIKBAP Accounting sebagai berikut: 
RABIT : Jurnal Teknologi dan Sistem Informasi Univrab

Volume 3 No. 2 | Juli 2018 : 93-107

Tabel 1. Daftar Perkiraan Laporan keuangan

\begin{tabular}{|c|c|c|}
\hline $\begin{array}{l}\text { Kode } \\
\text { Akun }\end{array}$ & Akun & Keterangan \\
\hline 1-1 & ASSET & Kelompok \\
\hline $1-11$ & ASSET LANCAR & Golongan \\
\hline $1-111$ & DAN & Jenis \\
\hline & SETARA KAS & \\
\hline $1-112$ & PERSEDIAAN & Jenis \\
\hline $1-113$ & $\begin{array}{l}\text { PIUTANG } \\
\text { USAHA }\end{array}$ & Jenis \\
\hline $1-114$ & WESEL TAGIH & Jenis \\
\hline $1-115$ & PERLENGKAPAN & Jenis \\
\hline $1-116$ & $\begin{array}{l}\text { BIAYA } \\
\text { DIBAYAR } \\
\text { DIMUKA }\end{array}$ & Jenis \\
\hline $1-117$ & $\begin{array}{l}\text { PAJAK DIBAYAR } \\
\text { DIMUKA }\end{array}$ & Jenis \\
\hline $1-21$ & $\begin{array}{l}\text { ASET TIDAK } \\
\text { LANCAR }\end{array}$ & Golongan \\
\hline $1-211$ & $\begin{array}{l}\text { PROPERTI } \\
\text { INVESTASI }\end{array}$ & Jenis \\
\hline $1-212$ & ASET TETAP & Jenis \\
\hline $\begin{array}{l}1- \\
2121\end{array}$ & PERALATAN & Jenis \\
\hline $\begin{array}{l}1- \\
21210\end{array}$ & $\begin{array}{l}\text { AKUMULASI } \\
\text { PENYUSUTAN } \\
\text { PERALATAN }\end{array}$ & Urutan \\
\hline $\begin{array}{l}1- \\
2122 \\
\end{array}$ & GEDUNG & Jenis \\
\hline $\begin{array}{l}1- \\
21220\end{array}$ & $\begin{array}{l}\text { AKUMULASI } \\
\text { PENYUSUTAN } \\
\text { GEDUNG }\end{array}$ & Urutan \\
\hline $\begin{array}{l}1- \\
2123\end{array}$ & TANAH & Jenis \\
\hline $\begin{array}{l}1- \\
21230\end{array}$ & MESIN & Jenis \\
\hline $1-$ & AKUMULASI & Urutan \\
\hline
\end{tabular}

\begin{tabular}{llc}
\hline 2124 & $\begin{array}{l}\text { PENYUSUTAN } \\
\end{array}$ & \\
\hline $1-213$ & ASET TIDAK & Jenis \\
& BERWUJUD & \\
\hline $1-214$ & ASET LAINNYA & Jenis \\
\hline $\mathbf{2 - 1}$ & KEWAJIBAN & Kelompok \\
\hline $\mathbf{2 - 1 1}$ & KEWAJBAN & Golongan \\
& JANGKA & \\
& PENDEK & \\
\hline $2-111$ & HUTANG USAHA & Jenis \\
\hline $2-112$ & HUTANG BANK & Jenis \\
& JANGKA & \\
& PENDEK & \\
\hline $2-113$ & HUTANG PAJAK & Jenis \\
\hline $2-114$ & $\begin{array}{l}\text { BIAYA YANG } \\
\text { MASIH HARUS }\end{array}$ & Jenis \\
& DIBAYAR & \\
\hline
\end{tabular}

\begin{tabular}{lll}
\hline 2-21 & KEWAJIBAN & Golongan \\
& JANGKA & \\
& PANJANG
\end{tabular}

$2-211$

Jenis

JANGKA

PANJANG

2-212 KEWAJIBAN Jenis

IMBALAN

PASCA KERJA

2-213 HUTANG Jenis

OBLIGASI

2-214 HUTANG Jenis

HIPOTEK

\begin{tabular}{llc}
\hline 3-1 & MODAL & Kelompok \\
\hline 3-11 & MODAL & Golongan
\end{tabular}

DISETOR

3-21 SALDO LABA $\quad$ Golongan

3-211 SALDO LABA / Jenis

RUGI DITAHAN

3-212 SALDO LABA / Jenis RUGI BERJALAN

3-213 PRIVE Jenis 
RABIT : Jurnal Teknologi dan Sistem Informasi Univrab

Volume 3 No. 2 | Juli 2018 : 93-107

\begin{tabular}{llc}
\hline $3-214$ & DEVIDEN & Jenis \\
\hline $\mathbf{4 - 1}$ & PENDAPATAN & Kelompok \\
\hline $4-111$ & PENJUALAN & Jenis \\
\hline $4-$ & RETURN & Urutan \\
1110 & PENJUALAN & \\
\hline $4-$ & POTONGAN & Urutan \\
1111 & PENJUALAN & \\
\hline $4-$ & HARGA POKOK & Urutan \\
1112 & PENJUALAN & \\
\hline $4-112$ & PENDAPATAN & Jenis \\
& LAIN-LAIN & \\
\hline $4-121$ & PEMBELIAN & Jenis \\
\hline $4-$ & RETURN & Urutan \\
1210 & PEMBELIAN & \\
\hline $4-$ & POTONGAN & Urutan \\
1211 & PEMBELIAN & \\
\hline 5-1 & BEBAN & Kelompok \\
\hline $\mathbf{5 - 1 1}$ & BEBAN & Golongan \\
& PENJUALAN & \\
\hline $5-111$ & BIAYA IKLAN & Jenis \\
\hline $5-112$ & BIAYA ANGKUT & Jenis \\
& PENJUALAN & \\
\hline $\mathbf{5 - 2 1}$ & BEBAN & Golongan \\
& ADMINISTRASI & \\
& DAN UMUM & \\
\hline $5-211$ & BIAYA & Jenis \\
& TELEPON, AIR & \\
& DAN LISTRIK & \\
\hline & & \\
\hline
\end{tabular}

\section{Perancangan Menu Sistem}

Menu pada sebuah sistem merupakan alat dalam menyelesaikan pekerjaan dalam menyajikan laporan keuangan. Tampilan menu pada SIKBAP Accounting dapat dilihat pada gambar berikut:

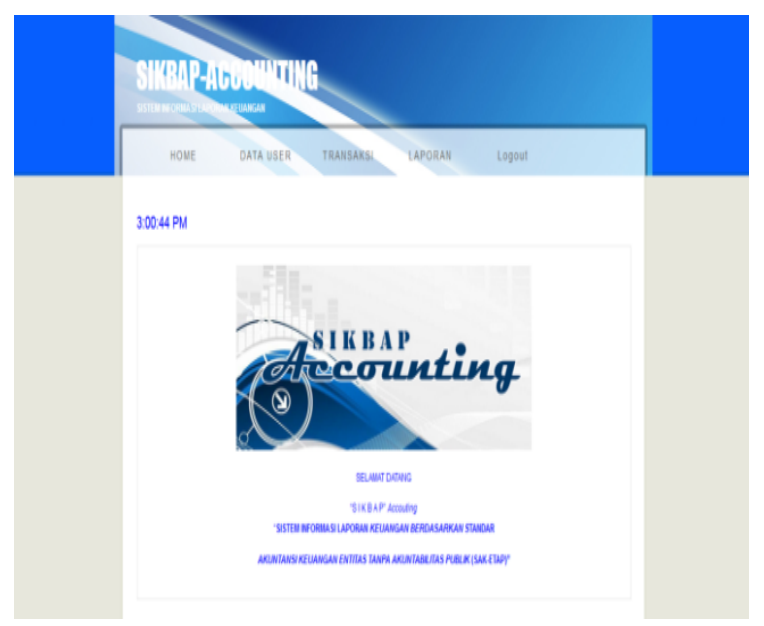

Gambar 11. Menu Sistem SIKBAP Accounting

Gambar di atas, menyajikan menu sistem SIKBAP terdiri dari Home, yang merupakan tampilan awal sistem, data user, transaksi, laporan dan logout untuk keluar dari sistem atau menu ditutup. Penyajian laporan keuangan dengan form input yang disediakan dalam rancangan akan menampilkan secara otomatis.

\section{Tampilan Transaksi}

Tampilan pada menu transaksi menyajikan laporan yang menunjukan proses laporan keuangan mulai dari neraca saldo awal, jurnal umum, buku besar, neraca saldo dan jurnal penyesuaian. Adapun laporan dari masing-masing transaksi sebagai berikut: 
RABIT : Jurnal Teknologi dan Sistem Informasi Univrab

Volume 3 No. 2 | Juli 2018 : 93-107

\begin{tabular}{|c|c|c|c|}
\hline \multicolumn{4}{|c|}{$\begin{array}{l}\text { PT HIJRAH PRIMA UTAMA } \\
\text { NERACA SALDO AWAL } \\
\text { PER DESEMBER } 2016\end{array}$} \\
\hline KETERANGAN & REF & DEBET & KREDIT \\
\hline kaS & & Rp 155.000 .000 & \\
\hline PIUTANG USAHA & & Rp $\quad 178.000 .000$ & \\
\hline PERSEDIAAN & & $\begin{array}{ll}\operatorname{Rp} \quad 16.200 .000 \\
\end{array}$ & \\
\hline PERLENGKaPAN KANTOR & & Rp $\quad 12.000 .000$ & \\
\hline ASET TETAP & & Rp $\quad 460.000 .000$ & \\
\hline AKUM. PENYUSUTAN ASET TETAP & & & Rp 21.200 .000 \\
\hline UTANG USAHA & & & Rp 125.000 .000 \\
\hline UTANG BANK & & & $\operatorname{Rp} \quad 330.000 .000$ \\
\hline MODALSAHAM & & & Rp 250.000 .000 \\
\hline LABA DITAHAN & & & $\operatorname{Rp} \quad 95.000 .000$ \\
\hline TOTAL & & $\operatorname{Rp} 821.200 .000$ & Rp 821.200 .000 \\
\hline
\end{tabular}

Gambar 12. Laporan Neraca Awal SIKBAP

\section{Accounting}

\begin{tabular}{|c|c|c|c|c|}
\hline \multirow[t]{2}{*}{ TANGGAL } & KTTLRANGAN & REF & Dtaet & KREDIT \\
\hline & & & & \\
\hline 4 & PЕМВЕบАN & & $\begin{array}{|ll|}R p & 26.000 .000 \\
\end{array}$ & \\
\hline & UTANG USAHA & & & $\begin{array}{ll}R p & 26.0000000\end{array}$ \\
\hline 6 & PISLENGXAPAN KANTOR & & $\begin{array}{|ll|}R g & 2.500 .000 \\
\end{array}$ & \\
\hline & Kas & & & Rp $\quad 2500.000$ \\
\hline 12 & \begin{tabular}{|l} 
UTANG USAHA \\
\end{tabular} & & $\begin{array}{|ll|}R p & 22000.0000 \\
\end{array}$ & \\
\hline & kAs & & & Rp $\quad 22.000 .000$ \\
\hline 12 & \begin{tabular}{|l|} 
ASET TETAP \\
\end{tabular} & & \begin{tabular}{|l|l|} 
Rp & 4.2000000 \\
\end{tabular} & \\
\hline & KAS & & & $\begin{array}{ll}\mathrm{RP} & 4.200 .000 \\
\end{array}$ \\
\hline 19 & SIAYA BUNGSA & & $\begin{array}{|ll|}R \rho & 1.500 .000 \\
\end{array}$ & \\
\hline & KAS & & & Rp $\quad 1.500 .000$ \\
\hline 20 & SIAYA IKLAN & & $\begin{array}{|ll|}R p & 2.500 .000 \\
\end{array}$ & \\
\hline & kas & & & $109 \quad 2.500 .000$ \\
\hline 23 & PIUTANG USAMA & & Rp 22.000 .000 & \\
\hline & PENuUalan & & & $R p \quad 22.000 .000$ \\
\hline 22 & Kas & & \begin{tabular}{|l|l|}
$R p$ & 36000.000 \\
\end{tabular} & \\
\hline & POTONGAN PENUUALAN & & $\begin{array}{|ll|}R p & 1.000 .000 \\
\end{array}$ & \\
\hline & PENUUALAN & & & Rp $\quad 37.0000000$ \\
\hline 23 & PENGAFUAN & & \begin{tabular}{|l|l|}
$R P$ & 35000.000 \\
\end{tabular} & \\
\hline & POTONGAN PEMABENAN & & & $\begin{array}{ll}R p & 2.000 .000 \\
\end{array}$ \\
\hline & KAS & & & $\begin{array}{ll}R P & 33.0000000 \\
\end{array}$ \\
\hline 26 & SIAYA PENGIRIMANV & & $\begin{array}{|ll|}\text { Rp } & 1.500 .000 \\
\end{array}$ & \\
\hline & kas & & & Rp $\quad 1.500 .000$ \\
\hline 28 & BLAYA GMI & & $\begin{array}{|ll|}R p & 2.700 .000 \\
\end{array}$ & \\
\hline & KAS & & & $\begin{array}{ll}R p & 2.700 .000 \\
\end{array}$ \\
\hline & & & & 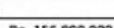 \\
\hline & TOTAL & & Rp 156.900.000 & Rp 156.900.000 \\
\hline
\end{tabular}

Gambar 12. Laporan Neraca Awal SIKBAP Accounting
PT HURAH PRIMA UTAMA

BUKUBEAR

PENOOE DESEMBER 2016

\begin{tabular}{|c|c|c|c|c|c|}
\hline & & & & \multicolumn{2}{|c|}{5000} \\
\hline & & & & Destr & KREOT \\
\hline & & & & & \\
\hline & S.600 ANAL & Rp 1350000.000 & & Ro 1550000000 & \\
\hline & 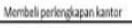 & & Re 25000000 & R9 15255000000 & \\
\hline & 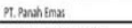 & & Re 20000000 & $R_{0}: 1005000000$ & \\
\hline & merrbel perabtan battor & & Re $\quad 4000000$ & Ro 1263000000 & \\
\hline & pentwaran bap bunep & & Be $\quad 1.5000000$ & Ro 1248000000 & \\
\hline & 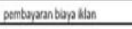 & & 892500000 & $R_{0} 12132000000$ & \\
\hline & menvul barmg dispare & $R p 0.36000000$ & & RQ 1583000000 & \\
\hline & 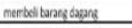 & & Bpo 31000000 & $R_{0} 123300004$ & \\
\hline & 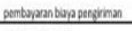 & & RQ 1500000 & R9: 123800000 & \\
\hline & pentbryzangil & & Re $\quad 2,2000000$ & ROQ 1212000000 & \\
\hline & Total & & & RQ 1212.10000000 & \\
\hline
\end{tabular}

Gambar 13. Laporan Jurnal Umum SIKBAP Accounting

PT HURAH PRIMA UTAMA

NERACA SALDO

PER DESEMBER 2016

\begin{tabular}{|c|c|c|c|}
\hline KETERANGAN & REF & DEBET & KREDIT \\
\hline kAS & & Rp 121.100 .000 & \\
\hline PIUTANG USAHA & & Rp 200.000 .000 & \\
\hline PERSEDIAAN & & Rp $\quad 16.200 .000$ & \\
\hline PERLENGKAPAN KANTOR & & Rp $\quad 14.500 .000$ & \\
\hline ASET TETAP & & Rp 464.200 .000 & \\
\hline AKUM, PENYUSUTAN ASET TETAP & & & Rp 21.200 .000 \\
\hline PENUUALAN & & & Rp 59.000 .000 \\
\hline POTONGAN PENUUALAN & & Rp1.000.000 & \\
\hline PEMBELIAN & & Rp $\quad 61.000 .000$ & \\
\hline POTONGAN PEMBEUAN & & & Rp 2.000 .000 \\
\hline UTANG USAHA & & & Rp 129.000 .000 \\
\hline UTANG BANK & & & $\operatorname{Rp} 330.000 .000$ \\
\hline MODAL SAHAM & & & $\operatorname{Rp} 250.000 .000$ \\
\hline LABA DITAMAN & & & $\operatorname{Rp} 95.000 .000$ \\
\hline BIAYAGAI & & 2.700 .000 & \\
\hline BIAYAIKLAN & & 2.500 .000 & \\
\hline BIAYA PENGIRIMAN & & 1.500 .000 & \\
\hline BIAYA BUNGA & & Rp 1.500 .000 & \\
\hline TOTAL & & Rp 886.200.000 & Rp886.200.000 \\
\hline
\end{tabular}

Gambar 14. Laporan Neraca Saldo

SIKBAP Accounting 


\section{PT HIJRAH PRIMA UTAMA \\ JURNAL PENYESUAIAN \\ PER DESEMBER 2016}

\begin{tabular}{|c|c|c|c|c||}
\hline \hline TANGGAL & KETERANGAN & DEBET & KREDIT \\
\hline \hline & & & & \\
\hline & 30 & BEBAN PERLENGKAPAN KANTOR & RP 1.000 .000 & \\
\hline & & PERLENGKAPAN KANTOR & & RP 1.000.000 \\
\hline & 30 & BEBAN PENYUSUTAN ASET TETAP & RP 500.000 & \\
\hline & & AKUM. PENUUSUTAN ASET TETAP & & RP 500.000 \\
\hline & 30 & BEBAN PENYUSUTAN GEDUNG & RP 1.000 .000 & \\
\hline & & AKUM. PENYUSUTAN GEOUNG & & RP 1.000.000 \\
\hline \hline & & & \\
\hline
\end{tabular}

Gambar 15. Laporan Jurnal Penyesuaian

\section{Tampilan Laporan}

Laporan yang disajikan sesuai dengan tujuan penelitian yaitu menyajikan laporan keuangan sesuai dengan objek perwakilan. Uji coba software penelitian dilakukan pada PT. Hijrah Prima Utama untuk perusahaan dagang dan manufaktur, sedangkan laporan keuangan perusahaan jasa CV. Khazanah Century Auto sudah mewakili akun yang diujikan. Hal ini disebabkan proses laporannya lebih lengkap yang juga sudah mewakili dari proses perusahaan jasa. Adapun bentuk ouput yang dihasilkan berupa laporan keuangan tahunan dapat dilihat sebagai berikut:

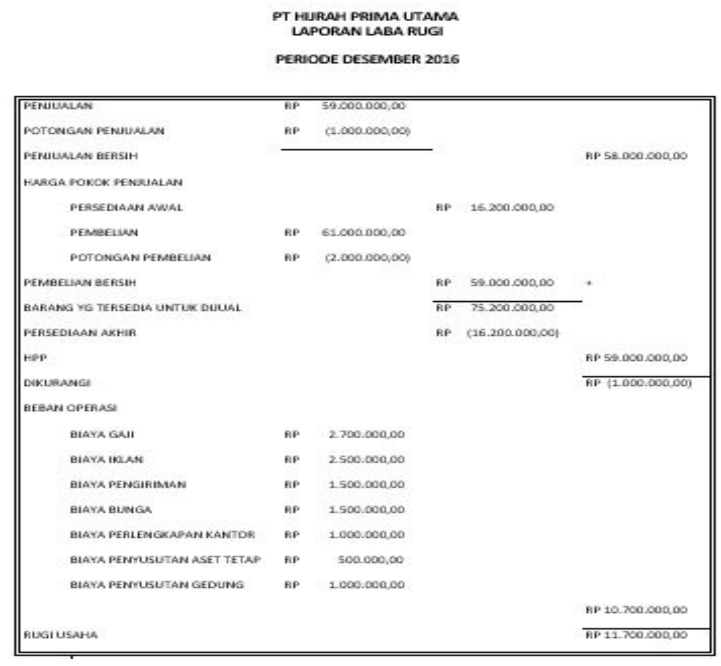

Gambar 16. Laporan Laba / Rugi SIKBAP Accounting

PT HIJRAH PRIMA UTAMA LAPORAN PERUBAHAN EKUITAS

PERIODE DESEMBER 2016

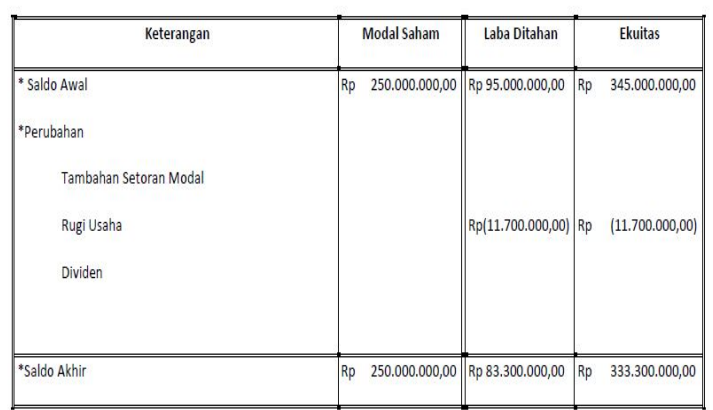

Gambar 17. Laporan Perubahan Ekuitas SIKBAP Accounting 


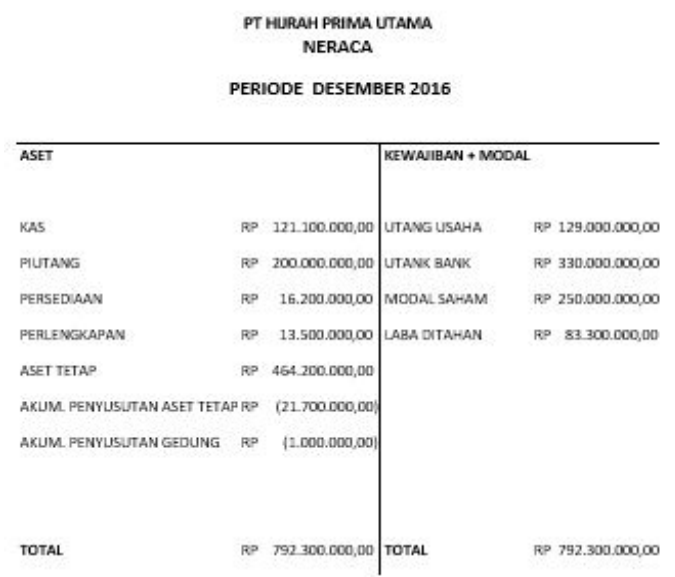

Gambar 18. Laporan Neraca SIKBAP Accounting

\section{Pembahasan}

Berdasarkan hasil penelitian di atas, maka dapat dilihat, bahwa rancangan sistem informasi laporan keuangan yang dibanggun sesuai dengan standar ETAP tetap mengikuti alunrnya proses akuntansi mulai dari pencatatan transaksi sampai dengan menyajikan laporan keuangan. Hal ini medukung penelitian (Sasono, 2015) yang menjelaskan bahwa pengembangan Sistem Informasi SIA UMKM pada tahap analisa dan desain memiliki kelebihan yaitu menggunakan standar akuntansi keuangan Entitas tanpa Akuntabilitas public (SAK ETAP) yang sesuai dengan kebutuhan pelaku UMKM Perusahaan Industri, selanjutnya sistem juga dibangun dengan menggunakan teknologi web yang memudahkan semua pelaku untuk menggunakan secara gratis.

Penelitian ini bertujuan untuk membantu pelaku usaha dalam menyusun laporan keuangan berstandar ETAP dan menyajikannya secara komputerisasi, sehingga pelaku UKM yang masih kurang memahami akuntansi dan pengelolaan keuangannya dapat terbantu menyusun laporan keuangan. Penjelasan ini dapat mendukung penelitian (Saragih \& Surikayanti, 2015) yang menjelaskan bahwa penerapan akuntansi yang dilakukan UKM Seram Kecamatan Medan Perjuangan secara dominan masih melakukan pencatatan atas transaksi secara manual, sedangkan yang menggunakan software akuntansi hanya beberapa UKM sehingga mereka masih terbatas dalam menyajikan laporan keuangan atas usaha mereka. Pelaku UKM tidak melakukan Jurnal ataupun Buku Besar dalam pencatatan transaksi didalam usaha mereka, sedangkan komponen yang disajikan pada UKM secara dominan hanya membuat laba-rugi, dan sedikit yang melakukan neraca dan peubahan ekuitas, sedangkan untuk komponen arus kas dan catatan atas laporan keuangan tidak ada yang membuat. Paparan tersebut memperkuat penelitian ini yang juga tidak menyajikan laporan arus kas dan catatan atas laporan keuangan.

\section{KESIMPULAN}

Berdasarkan landasan teori dan didukung oleh analisis data hasil penelitian, maka dapat disimpulkan sebagai berikut:

a. Rancangan sistem informasi proses akuntansi yang dibanggun diberi nama sistem informasi laporan keuangan berstandar Entitas Tanpa Akuntabilitas Publik (ETAP) yang akan disingkat dengan "SIKBAP" (Sistem Informasi Keuangan Berstandar ETAP) Accounting. 
b. Output yang akan ditampilkan adalah informasi laporan keuangan suatu usaha berupa: laporan laporan laba/rugi, laporan perubahan ekuitas, neraca, sehingga rancangan SIKBAP Accounting dapat membatu pelaku usaha dalam menyajikan laporan keuangan sesuai dengan standar.

\section{DAFTAR PUSTAKA}

[1] Rofiq, A. (2016). Rofiq Aunur. Retrieved from http://www.koransindo.com/news.php? $\mathrm{r}=1 \& \mathrm{n}=1 \&$ date $=$ 2016-01-14.

[2] Setyawan, P. (2017). Menumbuhkan Kebiasaan Menyusun Laporan Keuangan pada Usaha Kecil dan Menengah. Bisnis Dan Usahawan, II No. 7, 181-184.

[3] Salmiah, Neneng, I. \& I. F. S. (2015). Analisis penerapan akuntansi dan kesesuaiannya dengan standar Akuntansi keuangan entitas tanpa akuntabilitas publik (Pada UMKM di Kecamatan Sukajadi Binaan DisKop \& UMKM Kota Pekanbaru), 3(2), 212226.

[4] Suhairi. (2006). Persepsi Akuntansi Terhadap Overload Standar Akuntansi Keuangan (SAK) Bagi Usaha Kecil dan Menengah. Makalah Yang Disampaikan Pada SNAIX Padang.

[5] Rifqi Adi Jaya, L, M. (2009). FaktorFaktor Yang Mempengaruhi Persepsi Penggunaan Informasi Akuntansi Pada Usaha Kecil Dan Menengah (Studi Kasus Sentra Industri Kecil Patung batu di Desa Jati Pasar Kecamatan Trowulan, Kabupaten Mojokerto).

[6] Sutabri, T. (2012). Analisis Sistem Informasi. Yogyakarta: Andi Offset.
[7] Sutarman. (2012). Buku Pengantar Teknologi Informasi. Jakarta: Bumi Aksara

[8] Mardi. (2014). Sistem Informasi Akuntansi. Bogor: Ghalia Indonesia.

[9] Syafri, H. (2008). Analisa Kritis atas Laporan Keuangan. Jakarta: PT. Raja Grafindo Persada.

[10]Irham, F. (2012). Analisis Laporan Keuangan (Cetakan ke). Bandung: Alfabet.

[11]Rosa \& Salahuddin. (2011). Modul Pembelajaran Rekayasa Perangkat Lunak (Terstruktur dan Berorientasi Objek). Bandung: Modula.

[12] Sunyoto. Andi. 2007. Pemrograman Database dengan Visual Basic dan Microsoft SQL 2000. Yogyakarta: Andi Offset.

[13] Madcoms. (2010). Aplikasi Program PHP + MySQL untuk membuat website interaktif. . Yogyakarta: Andi Offset.

[14]Roestiyah, Strategi Belajar Mengajar. Jakarta: Rineka Cipta., 2012.

[15] Sasono, A. D. \& M. K. \& T. P. \& I. I. (2015). Analisis Dan Desain Sistem Informasi Akuntansi Usaha Mikro Kecil Dan Menengah (SIAUMKM) Berbasis Web Sebagai Standarisasi Laporan Keuangan UMKM Sesuai Standard Akuntansi Keuangan Entitas Tanpa Akuntabilitas Publik. Institut Teknologi Adhi Tama Surabaya, $387-$ 396.

[16] Saragih, F., \& Surikayanti. (2015). Analisis Penerapan Akuntansi dan Kesesuaiannya dengan SAK ETAP pada UKM Medan Perjuangan. Seminar Nasional Ekonomi Manajemen Dan Akuntansi (SNEMA) Fakultas Ekonomi Universitas Negeri Padang, (c), 452-461. 